\title{
KEPEMIMPINAN KETUA YAYASAN DALAM MEWUJUDKAN KUALITAS PENDIDIKAN DAN PEMBELAJARAN DI SD SWASTA
}

\author{
Lisdawati Muda \\ Institut Agama Islam Negeri Sultan Amai Gorontalo
}

\begin{abstract}
Abstrak
Lembaga pendidikan dasar /SD swasta merupakan sebuah organisasi formal untuk melaksanakan kegiatan pendidikan dan pembelajaran di tingkat dasar yang melibatkan peran yayasan, guru, peserta didik, orang tua dan semua stakeholder terkait. Di dalam sebuah lembaga pendidikan dasar khususnya SD berstatus swasta tentunya sangat dipengaruhi oleh peran yayasan dalam menggerakkan semua aspek yang meliputi seluruh proses pembelajaran. Terkait dengan hal tersebut, maka seyogyanya peran yayasan yang dimotori oleh Ketua Yayasan amat dibutuhkan bukan hanya sekedar memberi dan menerima kritik dan saran dalam rangka perbaikan dan pengembangan lembaga pendidikan akan tetapi lebih daripada itu seorang Ketua Yayasan diharapkan bisa menjalankan peran kepemimpinannya dalam mengayomi, mengatur, mengarahkan dan membimbing SDM di lembaga pendidikan. Demikian pula seorang Ketua Yayasan dituntut agar dapat menjalin komunikasi dan kerjasama yang baik dengan orang tua peserta didik (komite), pemerintah dan semua komponen yang berkepentingan dalam membangun, menumbuhkembangkan dan mempertahankan kualitas pendidikan khususnya di lembaga pendidikan dasar/SD swasta.
\end{abstract}

Kata Kunci: Kepemimpinan, Ketua Yayasan, Kualitas Pendidikan

\section{PENDAHULUAN}

Seperti yang diketahui bersama bahwa salah satu alasan pentingnya perbaikan dan pengembangan kualitas pendidikan di lembaga pendidikan dasar karena lembaga pendidikan dasar adalah tempat yang paling utama dalam membentuk watak, mendidik dan membimbing peserta didik sebelum mereka melanjutkan pendidikan di lembaga pendidikan selanjutnya. antara lain:

Penulis berpendapat, lembaga pendidikan dasar/SD swasta memiliki fungsi

1. Menjadi pusat pembentukkan pemahaman dasar tentang keagamaan, pembelajaran dasar ilmu pengetatahuan, teknologi, seni dan budaya.

2. Menciptakan corak atau ciri khas pembentukkan karakter yang baik dalam proses pendidikan dan pembelajaran.

3. Memberikan wawasan dan ilmu pengetahuan yang luas kepada para guru (tenaga pendidik) dan tenaga kependidikan (pegawai tata usaha) tentang lingkungan social dalam rangka mengembangkan tiga ranah kecerdasan (IQ,EQ,SQ). 
Intinya adalah secara umum diharapkan lembaga pendidikan dasar/SD swasta bertujuan memberikan pelayanan pendidikan dasar kepada seluruh lapisan masyarakat yang bekualitas dan terjangkau, professional, manusiawai berlandaskan prinsip bertanggung jawab, berempati, dan religious. Berdasarkan fungsi tersebut patut dicermati, peran semua stakehokder (pemerintah, swasta dan masyarakat) menjadi factor penentu dalam mencapai tujuan pendidikan khususnya di lembaga pendidikan dasar/ SD swasta yang melibatkan peran Ketua Yayasan sebagai pemimpin utama terselenggaranya proses pendidikan dan pembelajaran.

\section{PERAN KEPEMIMPINAN KETUA YAYASAN DAN KAITANNYA DENGAN KUALITAS PENDIDIKAN DAN PEMBELAJARAN DI SD SWASTA}

Seperti yang telah diketahui bersama, Ketua Yayasan dalam sebuah lembaga pendidikan berfungsi dan bertanggung jawab mengkoordinir semua kegiatan proses pendidikan dan pembelajaran demi terwujudnya visi dan misi lembaga. Kepemimpinan dalam pengelolaan lembaga pendidikan dasar/SD swasta merupakan rangkaian kegiatan manajemen sebuah lembaga pendidikan yang dapat berfungsi dan berjalan normatif dalam menentukan arah pencapaian tujuan sebuah lembaga pendidikan dasar/SD swasta. Terdapat tiga factor yang mendukung terlaksananya tugas kepemimpinan Ketua Yayasan dalam sebuah lembaga pendidikan dasar/SD swasta meliputi:

1. Faktor komunikasi

Faktor komunikasi sangat penting menentukan dan mendukung pelaksanaan kepemimpinan sebagai upaya terwujudnya kualitas pendidikan di lembaga pendidikan/SD swasta. Dalam sebuah lembaga pendidikan khususnya pada SD swasta kegiatan komunikasi merupakan rangkaian informasi yang melibatkan semua stakeholder antara dewan pembina yayasan, pengurus yayasan, pemerintah/swasta dan masyarakat, guru, pengurus dan anggota komite serta keterlibatan seluruh orang tua peserta didik. Pada bagian ini penulis lebih menyoroti kegiatan komunikasi yang dilakukan oleh Ketua Yayasan, yaitu menitikberatkan pada pemahaman, pengetahuan dan keterampilan mengirim dan menerima informasi mengenai pesan-pesan kebijakan, regulasi serta keputusan yang berlaku di sebuah lembaga dalam menjalankan kepemimpinan guna pemenuhan kualitas pendidikan di lembaga pendidikan dasar/SD swasta sesuai dengan yang diharapkan.

Penyampaian informasi yang memanfaatkan berbagai media komunikasi dilakukan Ketua Yayasan kepada pihak lain diaplikasikan dengan sebaik mungkin untuk menjadi perekat sebuah lembaga pendidikan/SD swasta. Selain itu di lembaga pendidikan dasar/SD swasta peran kepemimpinan Ketua Yayasan dalam pelaksanaan tugas dan tanggung jawabnya mengedepankan fungsi komunikasi yakni memahami, menguasai keterampilan berinterakasi baik dengan pegawai/guru tetap yayasan, pegawai/guru yang diperbantukan di yayasan, rekan sejawat maupun dengan atasan langsung dan berbagai pihak terkait. Sehubungan dengan pentingnya komunikasi dalam sebuah lembaga pendidikan, maka ada empat fungsi komunikasi yang efektif diterapkan di lembaga pendidikan dasar/SD swasta antara lain: 
1) Komunikasi berfungsi sebagai pengendali perilaku SDM di lembaga pendidikan (guru,pegawai)

Fungsi tersebut dapat berjalan maksimal apabila pegawai/guru diharuskan menjelaskan hambatan-hambatan dalam pelaksanaan tugas dan kewajiban yang harus dilaksanakan oleh pegawai/guru seperti mengajar, membimbing, mengatur administrasi sekolah dan lain sebagainya.

2) Komunikasi dipahami sebagai alat yang berfungsi untuk menumbuhkembangkan semangat bagi seluruh pegawai/guru. Fungsi ini dapat terlaksana jika Ketua Yayasan sebagai seorang pemimpin berkeinginan meningkatkan kinerja pegawai/guru, misalnya Ketua Yayasan menginformasikan seberapa baik hasil pekerjaan yang telah diselesaikan oleh pegawai/guru dan bagaimana strategi yang mesti dilakukan untuk meningkatkan dan mengembangkan kinerja para pegawai/guru sebagai upaya untuk membentuk dan meningkatkan kualitas pendidikan di SD swasta.

3) Komunikasi berfungsi mendeskripsikan emosi bagi Ketua Yayasan.

Pemimpin dalam hal ini Ketua Yayasan di lembaga pendidikan dasar/ SD swasta dinilai aktif berperan ketika pegawai/guru menjadi sumber utama dalam interaksi social. Interakasi komunikasi yang berlangsung dalam lembaga tersebut dapat menggambarkan perasaan kecewa ataupun perasaan puas terhadap kinerja dan prestasi mereka.

4) Komunikasi berfungsi sebagai salah satu pertimbangan dalam pengambilan keputusan, yaitu komunikasi memberikan informasi yang dibutuhkan perorangan dan kelompok memutuskan kebijakan lembaga dengan jalan menyajikan data dan sumber data agar mudah mengenal dan menilai berbagai alternatif kebijakan dan keputusan yang diambil. (Sopiah 2008:142) ${ }^{1}$

Di sebuah lembaga pendidikan dasar/SD swasta sangat penting menciptakan arus komunikasi sebagai factor pendukung terwujudnya kualitas pendidikan. Komunikasi yang dimaksud adalah komunikasi antara dua orang atau lebih, saling tukar menukar informasi dan pesan yang terkait dengan kegiatan proses pendidikan dan pembelajaran. Yaitu proses komunikasi yang terjadi antara Ketua Yayasan dan pengurus yayasan lainnya, pembina yayasan, para pegawai/guru dan semua unsur terkait dengan jalan mempertajam pemahaman yang diinginkan oleh pengirim/pemberi informasi yang nantinya sangat berdampak pada peningkatan dan pengembangan kualitas pendidikan di lembaga pendidikan dasar/SD swasta.

Oleh sebab itu berbagai hal yang disampaikan dan bagaimana teknik penyampaian sangat berpengaruh dalam kelancaran berkomunikasi. Komunikasi tidak hanya merangkai kata-kata menjadi kalimat melainkan komunikasi juga berkaitan dengan komponen nonverbal berupa perubahan ekspresi wajah, gerakan anggota badan lainnya serta irama dan intonasi suara pada saat berkomunikasi.

\footnotetext{
${ }^{1}$ Sopiah, Perilaku Organisasi. (Yogyakarta: Andi, 2008), hlm. 12.
} 
Komunikasi yang dilakukan Ketua Yayasan dengan berbagai pihak di lembaga pendidikan dasar/SD swasta dilakukan dalam rangka untuk menyampaikan gagasan/ide, emosi serta menjelaskan keinginan yang ingin dicapai. Di samping itu melalui komunikasi seorang Ketua Yayasan dapat pula mengekspresikan perasaan tidak puas terhadap kinerja pegawai/guru atau sebaliknya, keinginan memperoleh pengakuan, memperingatkan pegawai/guru, meningkatkan harga diri, memberi instruksi, memberi pertolongan, dan lain sebagainya. Semua aktivitas sosial maupun kegiatan di lembaga pendidikan sangat tergantung pada komunikasi sebagai media untuk berbagi ide, perasaan, dan sumber daya. Kesepakatan, pengambilan keputusan dan implementasi program di lembaga pendidikan dasar/SD swasta tidak mungkin berhasil jika arus komunikasi antara Ketua Yayasan dan seluruh elemen terkait tidak berjalan sebagaimana mestinya.

\section{MENERAPKAN GAYA MEMERINTAH DALAM MENGAYOMI DAN MEMPENGARUHI PEGAWAI/GURU}

Lembaga pendidikan dasar/SD swasta merupakan salah satu wadah berkumpulnya para guru beserta pegawai tata usaha yang datang dari berbagai lembaga pendidikan dan memiliki disipilin ilmu ataupun keterampilan berbeda. Dengan adanya perbedaan tersebut maka fungsi Ketua Yayasan ialah mengkoordinir penempatan dan pembagian tugas yang disesuaikan dengan kompetensi pegawai/guru dalam mengajarkan materi pelajaran, seperti: Tematik, Pendidikan Jasmani Olahraga dan Kesehatan, Fiqih, Qur'an Hadist, Akidah Akhlak, Sejarah Kebudayaan Islam, Tahfiz, bahasa Arab, Bahasa Inggris, IT, dan lain-lain.

Bagi SD swasta tentunya sangat diharapkan dapat mewujudkan proses pendidikan dan pembelajaran yang baik dan berkualitas melalui pemberian materi pelajaran yang telah dijadwalkan bersama ataupun materi yang diberikan sebagai tambahan jam pelajaran. Agar sebuah lembaga pendidikan dasar/SD swasta unggul dan berkualitas, maka peran seorang Ketua Yayasan diharapakan bisa menerapkan Strategi dan model Kepemimpinan yang tepat dalam mempengaruhi pegawai/guru yang memiliki kompetensi dan keahlian berbeda satu sama lain. Untuk mempengaruhi pegawai/guru di lembaga pendidikan dasar/SD swasta penulis mengutip pendapat dari Caludia Floretta (2009:91-93 $)^{2}$ bahwa dalam mempengaruhi orang lain terdapat beberapa model kepemimpinan beserta ciri-ciri model kepemimpinan yang dapat dilakukan oleh seorang pemimpin antara lain:

${ }^{2}$ The Art of Influence. Rahasia tentang Menanamkan Pengaruh dalam 10 menit. Jakarta: Prestasi Pustaka 


\section{Model Memberitahu/Model Seorang Analis:}

a. Lebih memilih logika daripada emosi

b. Menyampaikan argument atau ide dengan disertai alasan dan buktinya

c. Menekankan pada struktur dan organisasi

d. Suka menggabungkan atau menghubungkan dengan poin-poin lainnya

e. Cenderung berkembang tapi tidak jauh dari posisinya

Model Memerintah/Model seorang Pragmatis:

a. Menawarkan penghargaan/hadiah

b. Menggunakan kekuasaan yang lebih tinggi

c. Melakukan penawaran atau negosiasi

d. Menyebutkan dengan jelas tujuan dan harapannya

e. Ada ancaman atas ketidakpatuhan

Model Menebang/Model seorang Preservasionis:

a. Mencari dan menunjukkan kelemahan atau ketidakkonsistensian dari ide-ide orang lain

b. Menantang ide yang dianggap tidak praktis

c. Mempertahankan status quo

d. Mempertahankan posisinya.

\section{Model menjadi Sumber Mata Air:}

a. Cenderung fleksibel, bisa berubah setelah mendengarkan ide orang lain

b. Dengan aktif mendorong orang lain untuk memberikan saran mereka

c. Dengan aktif mendengarkan dan mencari tahu isyarat-isyarat baik verbal ataupun non verbal

d. Menyampaikan kembali pendapat orang lain

e. Cenderung membuka diri.

Model Menjual/Model seorang Ahli Strategi:

a. Menyampaikan ide sehubungan dengan keuntungan yang bisa dicapai seseorang untuk mewujudkan kebutuhan dan tujuannya (jelas atau tidak tertera dengan jelas)

b. Menggunakan strategi "penutupan" atau komitmen

c. Memberikan perhatian pada strategi pengambilan keputusan orang perorang.

d. Mencari tahu hambatan dan mengatasinya

Gaya Menyatukan/Gaya seorang Idealis

a) Menggunakan emosi daripada logika

b) Mencari tujuan yang sama

c) Memiliki orientasi untuk masa depan

d) Menggunakan bahasa, gambaran dan metafora secara gamblang.

Berdasarkan model kepemimpinan tersebut penulis dapat mengemukakan bahwa untuk kelancaran pelaksanaan proses pendidikan dan pembelajaran dalam rangka mencapai kualitas pendidikan di lembaga pendidikan dasar, maka model atapun strategi kepemimpinan seorang Ketua Yayasan adalah memadukan semua model kepemimpinan seperti yang telah disebutkan di atas. 


\begin{abstract}
Alasannya adalah SDM (guru dan pegawai) di lembaga pendidikan dasar/SD swasta cenderung memiliki pemahaman dan ilmu pengetahuan yang berbeda, dikarenakan oleh beberapa perbedaan mendasar antara lain:
\end{abstract}

\title{
1. Bakat dan minat
}

Perbedaan bakat dan minat antar sesama pegawai/guru sangat mempengaruhi teknik mengajar, bekerja dan membimbing peserta didik.

Seorang guru yang memiliki bakat dan minat di bidang seni yang mengajarkan materi selain seni (matematika, IPA,IPS, dll) seraya menyanyi, melukis ataupun membuat keterampilan-keterampilan lain yang berhubungan dengan mata pelajaran yang diberikan. Melalui teknik seperti itu para peserta didik di SD swasta merasa lebih bersemangat belajar dan tidak mudah bosan.

Teknik tersebut berbeda dengan seorang guru yang mengajar tanpa memiliki bakat dan minat di bidang seni. Guru yang tidak memiliki bakat dan seni cenderung mengajar lebih kaku sehingga membuat peserta didik merasa tertekan dan seolah-olah dipaksa untuk belajar.

\section{Pengalaman kerja}

Bagi seorang guru yang sebelumnya pernah mengajar dan bekerja serta memiliki pengalaman mengajar biasanya lebih percaya diri. Pemahaman, pengetahuan dan penguasaan terhadap setiap perubahan kurikulum, teknik mengajar serta membimbing peserta didik lebih mudah diterapkan oleh seorang guru yang telah memiliki pengalaman kerja. Sedikit berbeda dengan seorang guru yang belum memiliki banyak pemahaman, pengetahuan tentang tugas dan tanggung jawab seorang guru serta pengalaman beradaptasi di lingkungan lembaga pendidikan dasar/SD swasta. Sebagian guru yang minim pengalaman biasanya terlihat kaku dan gugup pada saat pertama kali melaksanakan proses pendidikan dan pembelajaran. Dibutuhkan waktu untuk menumbuhkembangkan keberanian, dan rasa percaya diri menunaikan tugas dan tanggung jawab sebagai seorang guru dan pendidik professional.

\section{Niat, Maksud dan Tujuan}

Tidak dapat dipungkiri setiap guru yang mengajar di lembaga pendidikan dasar/SD swasta mempunyai niat, maksud dan tujuan berbeda. Di antara guru yang datang melamar bekerja ada yang berniat, bermaksud dan bertujuan memenuhi panggilan jiwa, hanya menjadikan lembaga pendidikan dasar/SD swasta sebagai batu loncatan dan mencari pengalaman agar dapat diterima menjadi guru pada level lembaga pendidikan berikutnya (SMP, SMA,PT), karena tuntutan ekonomi, mempertahankan prestise, memenuhi permintaan dan harapan orang tua, keluarga, isteri, suami, dan lain sebagainya. Namun ada pula guru yang memang benar-benar niatnya tulus ikhlas karena Allah mengabdi tanpa paksaan orang lain atapun menuntut pembayaran gaji yang tinggi dan rela menerima kekurangan yang ada di lembaga pendidikan dasar/SD swasta tempat dia bekerja dan mengabdi. 
Untuk menyikapi berbagai macam perbedaan niat, maksud dan tujuan seperti yang telah dikemukakan sebelumnya maka penulis berpendapat, pemimpin di lembaga pendidikan dasar/SD swasta dalam hal ini Ketua Yayasan seyogyanya memiliki keterampilan dan keahlian memimpin. Mengatur seluruh pegawai termasuk guru dan pegawai yang mengabdi di lembaga pendidikan di bawah naungan yayasan yang dipimpinnya dapat dilakukan melalui penerapan gaya dan strategi kepemimpinan yang dinilai tepat sesuai dengan situasi dan kondisi yang terjadi di lingkungan lembaga pendidikan dasar/SD swasta. Strategi kepemimpinan yang dimaksud yakni melalui penerapan Strategi Kepemimpinan dengan "Gaya Menjual" atau lebih dikenal dengan Gaya seorang Ahli Strategi”

Menurut Claudia Floretta Model Menjual menggabungkan keahlian dan keterampilan yang terdapat pada model kepemimpinan Sumber Mata Air, membina suatu interaksi , memperhatikan dengan sungguh-sungguh, maupun keterampilan dan keahlian pada model Memberitahu misalnya menyampaikan ide-ide yang disertai dengan logika. Model ini juga menerapkan keahlian pada model Menyatukan dengan cara menciptakan visi yang sama di antara pegawai/guru yang sesuai dengan maksud sebuah lembaga pendidikan/SD swasta yang didirikan.

Dikatakan sebagai Model Menjual, karena tekniknya hampir sama seperti yang digunakan oleh para salesman. Dalam hal menjual, yang paling penting setelah interaksi tercipta adalah mempelajari, memahami mengenai berbagai item yang bisa dipelajari dan dipahami yang berhubungan erat dengan orang-orang ataupun pegawai/guru yang menjadi sasaran utama dalam menjalankan aktivitas kepemimpinan. Jika dimaknai Model Menjual dalam sebuah interkasi perniagaan biasanya menimbulkan pertanyaan di kalangan konsumen seperti "Laba apa yang bisa saya petik dari produk ini?" Sebagai seorang pemimpin yang ahli strategi tentunya dengan mudah menjawab pertanyaan tersebut. Yang pertama kali dilakukan adalah dengan teknik mengetahui dorongan dasar dari si penanya, seperti yang dituliskan oleh Maslow tentang hierarki kebutuhan mendasar manusia yang memiliki perbedaan antara satu dengan yang lain.

Pada level terbawah dari hierarki kebutuhan manusia menurut Maslow ialah setiap manusia berkebutuhan untuk mempertahankan kehidupan, berkebutuhan untuk patut menikmati kehidupan dengan perasaan aman dan nyaman. Di samping itu kebutuhan manusia lainnya: mempunyai kebutuhan hidup sebagai makhuk social (saling ketergantungan satu sama lain), kebutuhan untuk menjadi bagian dari sebuah kelompok, kebutuhan hidup berkeluarga. Pada puncak motivasi kehidupan seorang manusia berkebutuhan terhadap pengakuan status, prestasi, martabat, percaya diri dan kesempatan aktualisasi diri. Kebutuhan-kebutuhan ini semuanya memiliki peran yang besar dalam memotivasi diri bagi setiap orang, termasuk pegawai/guru yang bekerja di lembaga pendidikan/SD swasta. Demikian pula penempatan setiap kebutuhan berada pada level yang sering berubah-ubah sesuai dengan situasi dan kondisi tertentu. Seorang guru yang bekerja dengan maksud untuk meningkatkan taraf perekonomian keluarga berada pada 
level pertama, akan tetapi sewaktu-waktu bisa berubah apabila suatu saat dia berada dalam kondisi yang kurang sehat, maka level kebutuhan untuk memperoleh kenyamanan menempati level pertama dibandingkan tujuan bekerja adalah mendapatkan gaji yang tinggi.

Sehubungan dengan strategi kepemimpinan melalui Model Menjual seorang pemimpin termasuk Ketua Yayasan salah satu yang paling urgen dalam mempelajari dan memahami segala sesuatu yang berhubungan erat dengan orang-orang yang sedang dipimpin berkaitan dengan kebutuhan mendasar mereka yang bermanfaat sebagai pemberi motivasi bagi mereka. Misalnya seorang guru yang memiliki kebutuhan mendasar adalah mendambakan perasaan aman dan nyaman, maka sebagai seorang pemimpin Ketua Yayasan pada saat menyampaikan gagasan sepantasnya menitik beratkan pada kekuatan dan kestabilan gagasan yang disampaikan. Bagi seorang guru yang dipimpin dan dipengaruhi yang termotivasi oleh perwujudan kebutuhan rasa aman dan nyaman, maka pada saat menyampaikan gagasan hendaknya dengan cara yang lemah lembut, memberikan kesempatan yang seluas-luasnya kepada dia untuk memberikan tanggapan, pertanyaan terhadap gagasan yang disampaikan. Ketua Yayasan tidak diharuskan menerapakan Model Menjual dengan cara yang terlalu berlebihan, karena justru membuat pegawai/guru akan merasa tertekan dan tidak nyaman bekerja.

Model Menjual yang dapat diimplementasikan oleh Ketua Yayasan kepada guru/pegawai di SD swata yang menginginkan rasa aman dan nyaman bekerja, lebih tepat adalah menawarkan konsep bekerja yang jauh dari intervensi seorang pemimpin. Konsep ini bermakna Ketua Yayasan hendaknya memberikan amanah, tanggung jawab dan peluang besar bagi guru menemukan serta mengimplementasikan setiap strategi mengajar, bekerja, mendidik para peserta didik sesuai yang dinilai aman dan nyaman bagi dia dan orang lain. Sedikit berbeda dengan seorang guru bekerja yang lebih menitikberatkan pada factor ekonomi, maka sebagai ketua yayasan sesuatu yang menarik ditawarkan melalui Model Menjual adalah penawaran tentang keberhasilan mengajar dan bekerja selalu membawa dampak positif terhadap pendapatan yang diterima. Demikian pula kegagalan dan tidak serius bekerja berakibat pada pengurangan pendapatan yang bila kesalahan ini dilakukan secara terus-menerus akan berdampak negative terhadap penghasilan sehingga akan berpengaruh pada factor ekonomi. Menghadapi pegawai ataupun guru di SD swasta yang lebih berorientasi pada penghasilan,maka Model Menjual yang bisa dijalankan Ketua Yayasan senantiasa tegas, terbuka menjelaskan indicator yang terukur terkait dengan dampak yang terjadi baik pengaruh positif maupun pengaruh negative atas prestasi kerja dan impilkasinya bagi penghasilan yang diperoleh. Sementara bagi guru yang mendambakan pengalaman kerja sebagai Ketua Yayasan tentunya bisa menawarkan Model Menjual melalui pemberian kesempatan kepada guru yang ingin mendapatkan pengalaman lebih besar dari profesinya sebagai seorang pendidik untuk lebih banyak tampil mengikuti kegiatan yang dinilai dapat menambah wawasan dan pengalaman yang diinginkan. Oleh karena itu pembinaan secara langsung dan bertatap muka dengan para guru, mengundang mereka ke ruangan, atapun mengunjungi mereka ke rumah merupakan senjata paling ampuh untuk menggerakkan 
potensi mereka agar senatiasa selalu memberikan yang lebih baik bagi pengembangan lembaga pendidikan dasar/SD swasta. Perlakuan adil Ketua Yayasan kepada semua guru/pegawai bukan berarti pemberian reward dan punishment yang merata dari sisi kuantitas, akan tetapi perilaku adil yang ditunjukkan seorang Ketua Yayasan lebih mendepankan pada pertimbangan kebutuhan mendasar mereka yang melatar belakangi tujuan mereka bekerja di lembaga pendidikan SD swasta. Ketua Yayasan sebagai koordinator pelaksanaan proses pendidikan dan pembelajaran hendaknya lebih memahami bahwa tidak semua guru ataupun pegawai cocok diinstruksikan melaksanakan tugas dan tanggung jawabnya dengan sistim yang tegas dan lantang, maupun sebaliknya. Semua tergantung pada kebutuhan mendasar yang didambakan setiap guru atapun pegawai sehingga mengharuskan Ketua Yayasan terampil dan ahli dalam menjalankan aktivitas kepemimpinan demi terwujudanya visi dan misi di SD swasta yang berorietntasi pada pencapaian kualitas.

Kepemimpinan Ketua Yayasan melalui Model Menjual merupakan deskripsi bagi kemampuan Ketua Yayasan yang ahli strategi dalam memimpin sebuah lembaga khususnya lembaga pendidikan SD swasta. Penempatan Model Menjual terhadap masingmasing guru ataupun pegawai yang memiliki kebutuhan berbeda antara satu dengan lainnya memberi kesan bagi setiap guru bahwa Ketua Yayasan adalah sosok pemimpin yang paling mengerti kebutuhan guru/pegawa, kelebihan dan kekurangan guru/pegawai dan kebutuhan lain yang dinilai dapat mengembangkan kualitas pendidikan dan pembelajaran di SD swasta. Apabila terjadi kesenjangan antara kepemimpinan Ketua Yayasan dengan para guru/pegawai dibiarkan terjadi terus menerus tanpa mencari solusi dan titik temu, maka akan sangat sulit menentukan arah tujuan yang ingin dicapai oleh sebuah lembaga pendidikan termasuk SD swasta. Secara general diperlukan hasil sebuah konsep dan strategi implementasi kepemimpinan menyeluruh, lebih khusus terhadap penemuan konsep pengelolaan SD swasta agar pencapaian visi dan misi sekolah diperoleh dengan maksimal. Kepemimpinan Ketua Yayasan yang efektif lebih memudahkan terwujudnya suatu tatanan program kerja yang terencana, terorganisir, teraktualisasi dan terkontrol dengan baik sehingga tujuan pendidikan dan pembelajaran yang diharapkan dapat terwujud.

\section{MENUMBUHKEMBANGKAN KARAKTER RELIGIOUS DALAM KEPEMIMPINAN}

Kesadaran terhadap tugas dan tanggung jawab yang diamanahkan kepada seorang Ketua Yayasan bukanlah perkara mudah dan sederhana. Di pundak seorang Ketua Yayasan memikul amanah besar membawa SD swasta yang dikoordinirnya menjadi lembaga yang diminati masyarakat. Kepiawaian Ketua Yayasan dalam berkomunikasi dan memilih strategi serta model kepemimpinan yang cocok diterapkan di SD swasta akan lebih maksimal dan nyaris sempurna jika dipadukan dengan pengembangan karakter religious dalam menjalankan tugas kepemimpinan.

Tugas ataupun peran Ketua Yayasan sebagai seorang pemimpin secara meluas dapat diartikan sebagai suatu bagian penting yang menuntut pula kesiapannya memiliki 
berbagai keterampilan, kesiapan mengasah ketajaman berpikir, merasa dan memahami serta kemauan dan kesadaran memiliki sifat dan sikap tertentu yang dinilai baik, bermanfaat dan tidak menyimpang dari ajaran agama yang dikenal dengan karakter religious.

Untuk menjadi Ketua Yayasan yang amanah, cerdas dan bertanggung jawab tidak terlepas dari pentingnya menumbuh kembangkan karakter. Menjadi Ketua Yayasan perlu menghindari sifat arogan, egois dan perasaan ingin menguasai segala bentuk yang ada di lembaga pendidikan yang dipimpinnya. Sebagai pemimpin yang baik maka sepantasnya Ketua Yayasan mampu membangun dan mengembangkan karakter terpuji demi menjamin kelangsungan jalannya kepemimpinan sebagai bukti tanggung jawab kepada Allah Swt. Membentuk dan mengembangkan karakter religious harus dilakukan dengan jalan memupuk sifat dan perilaku terpuji serta senantiasa berusaha untuk selalu menghindari sifat dan perilaku yang bertentangan dengan nilai dan ajaran agama dan diharapkan dapat memberikan corak tersendiri terhadap pribadi seorang Ketua Yayasan.

Seorang Ketua Yayasan yang mampu menjalankan aktivitas kepemimpinan dilandasi dengan iman dan taqwa sebagai tanggung jawab seorang pemimpin berkarakter akan selalu dirindukan, terhormat dan insya mulia di sisi Allah Tuhan YME. Keberhasilan kepemimpinan Ketua Yayasan yang berkarakter religious dipastikan dapat menjadikan lembaga pendidikan dasar/SD swasta sebagai lembaga pendidikan yang bukan hanya dikenal karena ketersediaan infrastruktur modern dan berdaya saing, serta tanggap menghadapi perkembangan zaman, akan tetapi kepemimpinan Ketua Yayasan berkarakter religious mampu menempatkan lembaga pendidikan dasar/SD swasta sebagai lembaga pilihan utama yang dipercaya masyarakat.

\section{PENUTUP}

Ketua Yayasan berkarakter religius senantiasa menyadari bahwa amanah yang diembannya adalah rangkaian ibadah yang harus ditunaikan sebagai bukti tanggung jawab bukan saja kepada pembina dan pendiri yayasan kepada pemerintah dan masyarakat akan tetapi lebih dari pada itu dia menyadari sepenuhnya amanah kepemimpinan dipertanggung jawabkan di hadapan Allah Swt sebagai Sang Khalik Pemilik Segala Kekuasaan.

\section{DAFTAR PUSTAKA}

Floretta, Claudia. The Art of Influence. Rahasia tentang Menanamkan Pengaruh dalam 10 menit. Jakarta: Prestasi Pustaka, 2009.

Muda, Lisdawati. Kepemimpinan Rumah Sakit. Gorontalo: El-Qisty, 2011. Kepemimpinan Manusia Berkarakter. Gorontalo: IAIN Sultan Amai Pres, 2015.

Sopiah, Perilaku Organisasi. Yogyakarta: Andi, 2008. 